\title{
ГОРОДА РОССИЙСКОЙ АРКТИКИ В ПОСТОЯННОМ КРУГОВОРОТЕ ИЗМЕНЕНИЙ
}

A рктическая урбанизация не является вещью в себе, она «значительно переплетена с более широким контекстом» регионального и глобального развития. ${ }^{1}$ Российская часть Арктики наиболее интенсивно осваивалась в советский период. В это время основной целью ее масштабного освоения была в первую очередь необходимость обеспечить ресурсы для индустриализации. Начиная с конца 1920-х годов по всему Северу стали разрабатываться месторождения - строились шахты и карьеры, создавались научные и метеорологические станции и военные базы. Не менее важной была и цель - установить и поддерживать контроль над обширной малозаселенной территорией. ${ }^{2}$ На протяжении всего советского периода городская застройка была сосредоточена вокруг индустриальных комплексов, и ее развитие было тесно связано с обеспечением промышленных предприятий рабочей силой. Преимущественно строились не временные поселения, а возводились с нуля новые города и стационарные поселки там, где ранее никогда не было постоянных населенных пунктов.

Однако советский период не был гомогенным - в разные годы освоение Арктики осуществлялось по-разному. В 1930-е годы новые города и промышленные комплексы строились преимущественно силами заключенных ГУЛАГа и спецпереселенцев (раскулаченных крестьян, сосланных на Север). В этот период в городской застройке преобладало хаотически расположенное неблагоустроенное жилье барачного типа, рассчитанное на массовое заселение, бараки и шалманы, а на начальных этапах - палатки и землянки. ${ }^{3}$ Городское планирование было развито слабо и воплощалось лишь для центральных районов новых городов, где обычно располагались административные здания и благоустроенное жилье для разного рода специалистов и руководителей, составлявших не более 10-15\% жителей. Централизованная инфраструктура в тот период также была крайне неразвита, водоснабжение и канализация чаще всего отсутствовали.

Со смертью Сталина и ослаблением репрессивного аппарата принудительная миграция на Крайний Север сменилась добровольной. ${ }^{4}$ Однако в условиях непрекращающейся индустриализации оставалась потребность в значительном объеме рабочей силы. В этой связи государство развернуло массивную идеологическую кампанию, активно использующую риторику «покорения природы» и «освоения Севера». ${ }^{5}$ Кроме того, мигранты были мотивированы жить и работать на Крайнем Севере с помощью различных «северных» льгот (более высокая заработная плата, длительный отпуск). Не последнюю роль в «выманивании» людей из более климатически комфортных регионов СССР в Арктику стало целенаправленное улучшение условий жизни и благоустройство северных городов. Несмотря на унификацию строительства в СССР, Север стал единственным регионом, для которого было решено составить отдельный свод строительных правил. Начиная с 1960-х годов архитекторы сектора Севера Ленинградского филиала Академии строительства и архитектуры СССР разрабатывали множество модернистских архитектурных и планировочных проектов для Крайнего Севера. И хотя в основной

1 Laruelle M. (2019) The three waves of Arctic urbanisation. Drivers, evolutions, prospects//Polar Record. №. 55. C. $1-12$.

2 Bruno A. (2016) The Nature of Soviet Power. Cambridge University Press.

3 Меерович М.Г. (2017) Индустриализация в СССР. Жилище первостроителей городов-новостроек// Сибирские строители: события и судьбы. С. 406-418.

4 Siegelbaum L., Moch L. (2014) Broad is my native land. Repertoires and regimes of migration in Russia's twentieth century. Cornell University Press: Ithaca and London.

5 Bolotova A. (2014) Conquering nature and engaging with the environment in the industrialized Russian North. $\mathrm{PhD}$ Thesis//University of Lapland Faculty of Social Sciences. Rovaniemi, Finland: Lapland University Press. 
массе это были утопические проекты из серии «бумажной архитектуры», некоторые их элементы можно встретить в физическом воплощении. Например, крытые коридоры между зданиями, «скругленные дома». «Северная» архитектура была призвана сделать арктические города более приспособленными к суровым климатическим условиям, трансформируя Крайний Север из «экзотического региона в “обычную советскую территорию”». 6 В новых арктических городах, основанных в экстремальной природной среде, была постепенно обустроена разнообразная материальная и социальная инфраструктура, обеспечивающая комплекс городских услуг для всех жителей. Такие города должны были демонстрировать преимущества советского строя и служить полифункциональными опорными точками освоения Арктики. В отличие от других заполярных регионов мира, строительство населенных пунктов в Советской Арктике осуществлялось практически без оглядки на затраты, что привело к возникновению множества крупных урбанистических центров, которые вряд ли были бы созданы в столь экстремальных условиях при другом политическом режиме. ${ }^{7}$

Распад СССР привел к кризису ряда предприятий, ставших нерентабельными в новых экономических условиях, снижению инвестиций в науку и оборону, а также сокращению финансовой поддержки северных городов со стороны государства. В связи с нарушением действовавших в СССР механизмов перераспределения и координации ослабла система социального обеспечения арктических городов. Оказалось, что в экстремальных природно-климатических условиях новые города и поселки, часто расположенные в местах с разреженной транспортной инфраструктурой, не являются устойчивыми и чрезвычайно зависят от государственной поддержки. При столкновении неолиберальных реформ со специфической инфраструктурой, созданной в результате советского социального планирования, оказалось, что ее крайне сложно адаптировать к новым условиям, требованиям и технологиям. ${ }^{8}$ Совокупность таких факторов, как экономический кризис и деиндустриализация, зависимость от господдержки, слабая адаптивность и устаревание централизованных структур жизнеобеспечения, повлекла за собой упадок инфраструктур и значительную руинизацию множества арктических городов и поселков.

Современная Российская Арктика - это глубоко поляризованная территория, где зоны интенсивного освоения и экономического роста соседствуют с территориями упадка, где стремительно снижается численность населения и частично утрачивается социальный контроль над территорией. Как во всем мире, так и в России возникают новые режимы управления и стратегии адаптации сообществ к глобальным вызовам на Крайнем Севере. В постсоветский период российское государство сохраняет значительный интерес к развитию Арктического региона. Но при этом, с одной стороны, управление наследует черты советских интервенций, а с другой стороны, возникают совершенно новые подходы. Текущие практики управления и развития городов, степень контроля федерального центра и региональных администраций, сокращение социальных услуг для населения, отсутствие поддержки локальных инициатив и активистов вызывают много вопросов и споров в академическом и экспертном сообществах.

Данный специальный выпуск журнала «Городские исследования и практики» посвящен вопросам развития городов Российской Арктики в постсоветский период - как тех, что испытывают экономический бум, так и тех, что находятся в структурном кризисе. Статьи специального выпуска с разных сторон анализируют практики управления городами Российской Арктики и стратегии адаптации к различным проблемам, испытываемым ими, а также изменения, которые новые практики и стратегии вызывают. Вклад авторов из разных дисциплинарных традиций - географов, урбанистов и градостроителей, экономистов, социологов и антропологов - позволяет обеспечить критический взгляд на территорию сквозь междисциплинарную перспективу.

\section{Мария Гунько}

Редакторы-составители выражают благодарность Алле Болотовой за помощь в написании вступительного слова к этому номеру.

6 Калеменова Е. Какими могли быть арктические города. Режим доступа: https://arzamas.academy/materials/1821.

7 Hill F., Gaddy C.G. (2003) The Siberian curse: How communist planners left Russia out in the cold. Brookings Institution Press.

8 Collier S.J. (2011) Post-Soviet social: neoliberalism, social modernity, biopolitics. Princeton University Press. 